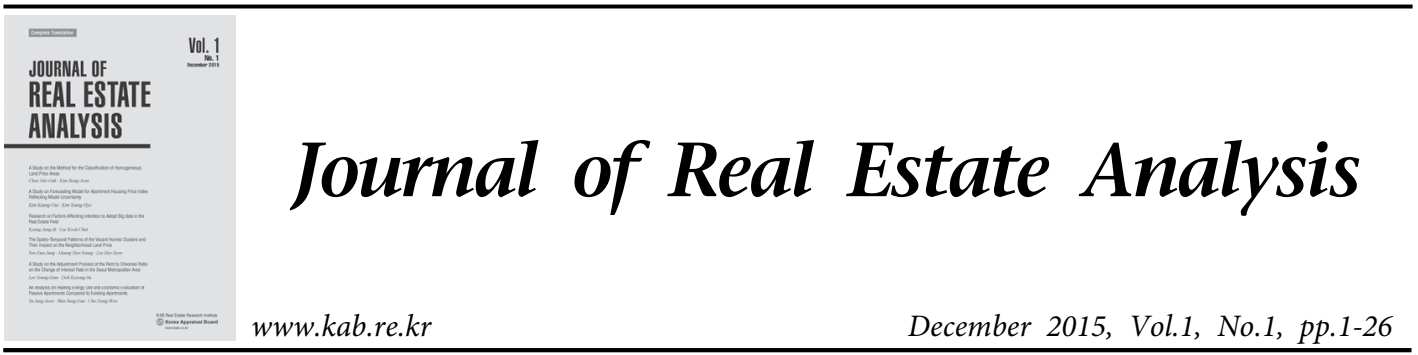

\title{
A Study on the Method for the Classification of Homogeneous Land Price Areas
}

\author{
Chae Mie-Oak $^{* *}$ and Kim Bong-Joon ${ }^{* * *}$
}

\begin{abstract}
| Abstract |
The Official Announcement System of Land Price involves the announcement of the Reference Prices of 500,000 standard lots among a total of 32 million lots across the nation, followed by the assessment of the land prices of individual lots based on the Reference Prices of standard lots and the land price index table.

Although it has been twenty five years since the introduction of the system, several problems still remain regarding the unequal distribution of standard lots, the imbalance between Announced Reference Prices and assessed individual lot prices and among assessed individual lot prices. Dividing lands into homogeneous land price areas (HLPAs) has previously been proposed; however, implementation of the method was difficult due to the difficulty in determining the proper spatial boundaries of the homogeneous price area.

This study aims to propose a method for and examine the validity and effectiveness of utilizing computers to classify HLPAs, categorizing into the same group lands of the same usage and the same land-use zone within the same administrative area, regardless of the spatial proximity of lands. The result shows that it is possible to classify HLPAs in a prompt and consistent manner, and to sub-classify the price layers according to the regional land price distribution, fitting the characteristics of each region. This study demonstrates that the proposed method can enhance efficiency in allocating and distributing standard lots, while restoring the balance between the standard lot price and assessed individual lot prices, and among assessed individual lot prices. It also shows that the systematic utilization of market prices allows assessed land prices to be closer to the market price.
\end{abstract}

Key Words: Official Announcement System of Land Price; Homogeneous Land Price Area (HLPA); Officially assessed land price; Closeness to market price

* This article is based on the study, which was primarily in the [Journal of Real Estate Analysis, Vol.1, No.1, pp.1 26, (in Korean)].

** Head of Institute, KAB Real Estate Research Institute, Korea Appraisal Board (Lead author, k25756@kab.co.kr)

*** Associate Research Fellow, KAB Real Estate Research Institute, Korea Appraisal Board (k04422@kab.co.kr) 


\section{Introduction}

\section{The Background and Purpose of the Study}

Korea has been industrialized and urbanized in a very short period of time since the 1960s. This rapid urbanization caused a lot of problems such as land price hike and land speculations. So the identification of land price and its trend has been one of the important policy interests, as well as anti-speculation and urban land supply.

The Official Announcement System of Land Price (OASLP) was introduced in 1989 in order to provide land price information required in various areas of public administration including compensation and taxation such as the Aggregate Land Tax, Excessively Increased Valuable Land Tax, and the Development Impact Fee System.

Lot prices under OASLP have been announced once a year by the Ministry of Land, Infrastructure and Transport (MLIT) since 1990. OASLP surveys and announces two types of lot prices; one is the standard lot price appraised by real estate appraisers on 500,000 standard lots, and the other is assessed individual lot price of approximately 32 million lots calculated by local officials based on the standard lot prices and the land price index table.
OASLP has enhanced the adequacy of official land prices by unifying the survey standards and methods that used to be surveyed and assessed by various administrative agencies. Problems of this system, however, have been pointed out such as the inefficiency of standard lot management, the low ratio of assessed price to market price, and the imbalance among assessed land prices of lots.

The underlying causes of these problems lie in lack of a system for selecting proper standard lots by analyzing homogeneous area through regional analysis. Such a lack of analysis of HLPAs based on regional analysis resulted in unequal distribution of standard lots and difficulties in identifying micro-changes in land prices.

The classification of HLPAs serves as a starting point for remedying problems in the overall official land price assessment system. Utilizing the information technology and devices, it is necessary to review classification methods of the HLPAs, which improve the balance in assessed prices among lots and enhance efficiency in the management of standard lots.

This paper aims to examine and propose a method for the classification of HLPAs, a starting point for enhancing the adequacy of assessed land prices, and the practical validity of the method. 


\section{Research Methods}

This paper investigates the concept of HLPAs and the existing methods for their classification, and proposes a new concept of HLPAs and a method for their classification. Next, it verifies the validity of the method for the classification of HLPAs, based on a case study. The validity of a HLPAs is verified in terms of the efficiency of standard lot allocation, the convenience of standard lot utilization, the balance among lot prices, and closeness to the market price.

To be more particular, first, as for verifying the efficiency of standard lot allocation and the convenience of standard lot utilization, the problems of the duplication and unequal distribution of standard lots are reviewed by analyzing the standard lot distribution of the current time and that by HLPAs; and how much the convenience of utilizing the standard lot price for the calculation of individual land prices are improved is analyzed.

Second, the effects of improvement in land price balance are analyzed in two aspects. First, disparities between standard lot prices and assessed individual lot prices are comparatively analyzed. Then, the diversity of land price distribution among lots is examined by analyzing a coefficient of variation for assessed individual land prices by HLPAs.
Third, changes in closeness to market price are analyzed by comparing market prices, assessed individual land prices, and calculated land prices by HLPAs.

\section{Review of Previous Research}

Discussions about the concept and necessity of the HLPAs have been around since the mid-1990s. Chae Mie-oak (1997) proposed a land price grouping method on the basis of the perception that it is difficult to classify HLPAs on the basis of spatial proximity, and analyzed the effects of method empirically.

This method can overcome the limitations of spatial area classification, for it classifies HLPAs by grouping land price levels according to key land price determinants such as the land-use zone and the land uses of lots; and has the advantage of indicating indirectly the influential spheres of standard lots by selecting comparative standard lots according to the characteristics of land and the levels of land price (Chae Mie-oak, 1997). Recently, Kim Bong-joon \& Choi Jin-ho (2015) applied to Guro-gu, Seoul, a method for classification of HLPAs based on the land price grouping method; and analyzed the validity of the method.

On the other hand, in the academic circle, there were studies on HLPAs classification 
that classified HLPAs through spatial econometric analysis based on the premise of spatial proximity. Yi Seong-kyu et al. (2004) classifies HLPAs, using spatial statistic methods such as k-means clustering, but shows limitations such as the arbitrariness of criteria for setting $\mathrm{K}$, the optimal number of clusters, and the difficulty in presenting definite standards and methods for defining the scope of a homogeneous area.

Yang Seoung-chul et al. (2006) classified homogeneous price areas by carrying out the K-means clustering analysis based on the index of situation similarity. The limitations of this method may be pointed out that it sets the current criteria for standard land distribution, which cause the unequal distribution of standard lots, as the upper bound of the optimal number of homogeneous price areas, thus having difficulty in guaranteeing the objective adequacy of the criteria for the classification of homogeneous price areas.

\section{The theoretical review and re-conceptualization of HLPAs}

\section{Review of the relationship between regional analysis and the HLPAs}

The survey and assessment system for
OASLP consists of four stages: the selection and management of standard lots, the price appraisal of standard lots, the preparation of the land price index table, and the assessment of individual lot prices. This is a series of procedures interconnected with one another, and an error or a problem in any particular procedure may develop into one that spreads throughout the whole land price assessment system.

The foundation for all land price appraisal and assessment, not just for OASLP, begins with regional analysis. The regional analysis has an inseparable relation with the classification of HLPAs, and it may be said that the regional analysis is the basis for all land-price surveys and appraisals.

The regional analysis is to analyze factors of diverse dimensions that influence the formation and changes of land prices. The determinants of land price are largely divided into three categories: socioeconomic determinants, regional determinants, and individual determinants. The socioeconomic determinants are nationwide and are decided by socioeconomic factors such as the income level, the trade balance, the money supply, and the trends of land demand and supply. The regional determinants are region-specific factors such as a regional development plan and the construction of a road or a subway, as shown in many cases where under the same 
socioeconomic conditions, land prices of a particular region rise, whereas those of the other regions decline or do not change. Lastly, the individual determinants are the micro level factors such as the physical characteristics and location factors of individual lots (Kim Yeong-pyo, 1985; Lee Tae-il, and Chae Mie-oak, 1986). As the influential range of the socioeconomic determinants is nationwide, the objects of regional analysis that are directly related to the HLPAs classification are the regional determinants and the individual determinants.

\section{Re-conceptualization of the HLPAs}

In the OASLP, the officially assessed individual lot is supposed to be calculated on the basis of a representative standard lot selected by regional analysis. Therefore, it may be said that the standard lot is theoretically a concept that represents one HLPA.

The current standard lots of OASLP, however, fail to present their specific HLPAs; in the case of urban areas, standard lots having similar characteristics are densely distributed more than necessary, whereas in non-urban areas, too few standard lots are distributed and fail to provide HLPAs, which results in difficulty in selecting the comparative standard lot and assessing individual lot prices (Chae Mie-oak, 1997).
The concept of the HLPAs defined by the OASLP indicates an area that has similar land price determinants and forms a similar price range (MLIT, 2015, Guidelines for the Survey and Assessment of Standard Lot). The Guideline for Standard Lot Survey and Appraisal provides definitions about the neighborhood, the similar area, and the same demand \& supply area. Here, the neighborhood refers to an area to which the standard lot belongs and that influences the formation of price for the standard lot land. The similar area indicates an area that has regional characteristics similar to those of the neighborhood and to which the standard lot does not belong. And the same demand \& supply area refers to an area where other lands, which are in the relations of substitution or competition with the standard lot and influence one another in the formation of price, are located; and includes the neighborhood and the similar area (MLIT, 2015, Guidelines for the Survey and Assessment of Standard Lot).

The concept of the HLPA used under the current OASLP refers to 'an area that has similar land characteristics and is geographically adjacent.' It may be said that the HLPAs cannot be established unless the two requirements of land characteristics and geographic proximity are satisfied. Such definition of the HLPA based on spatial proximity makes it difficult to classify and de- 
marcate HLPAs.

Land value is determined by land price determinants. The HLPA refers to a regional range where a similar level of land price is formed due to relatively homogeneous land price determinants. Such a spatial proximity-based concept of the HLPA defined by the OASLP does not agree with the pattern of land price formation. The land market is a local market, and it is often difficult to group and classify spatially adjacent lands into HLPAs because locational factors and price levels even for the adjacent lands vary with their surrounding conditions and the physical conditions of individual lands, as shown in Fig. 1.

It is required to reestablish a concept of HLPA that breaks away from spatial constraints, by making the utmost use of the computerized environment of various administrative information.
Therefore, this paper intends to define the concept of HLPA as "an area of lands that have similar land characteristics, albeit they are spatially separated, and form similar prices." To illustrate this concept, places of the same colors in Fig. 1 may be considered as HLPAs, though they are spatially apart.

\section{A method for the classification of HLPAs}

\section{The method of classification}

As for the HLPA classification method, careful consideration should be given to operational convenience, implementation consistency, and logical rationality for application. This paper classifies HLPAs, using the land price grouping method proposed by Chae (1997), a method that can classify lands

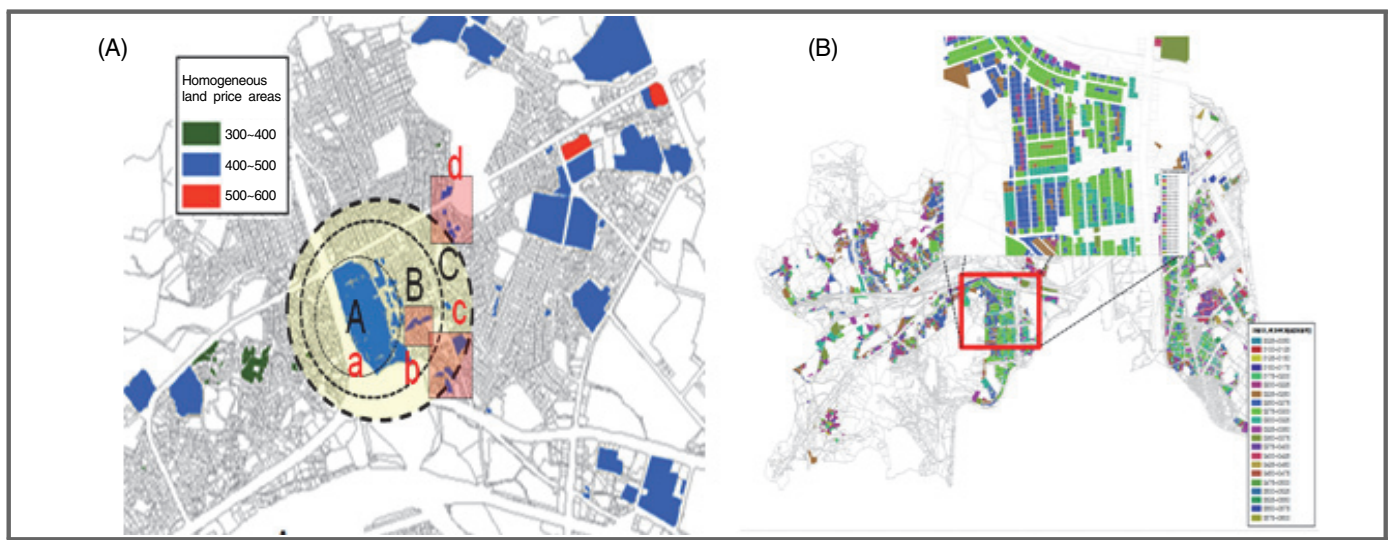

Source: Ibid, p.21

Fig. 1. An illustration of HLPAs (Residential in Guro) 


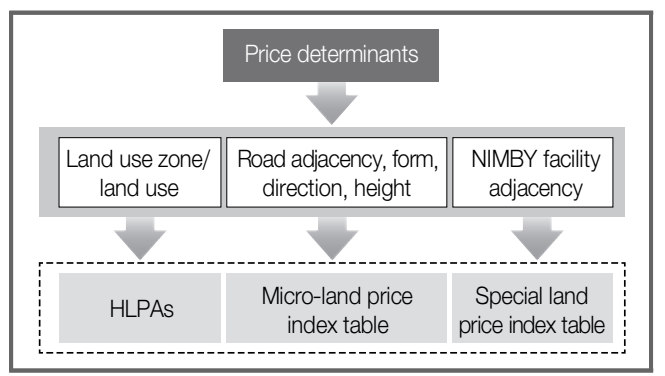

Fig. 2. Land price determinants and items of HLPAs classification

across the nation promptly by consistent standards.

As for the standards for the classification of the HLPAs, the primary classification is carried out centering around key land price determinants, and the secondary classification is carried out by the stratification of land price levels.

The first classification standard is the land price determinants. In the analysis of factors that are used for the primary HLPAs classification, the stepwise regression on land price determinants shows that influence on land price within $s i$, gun, and $g u$ (administrative district) is high in the order of the land-use zone and the land uses of lots, as shown in Table 1 As for the land-use zone, its influ- ence on land price is found to be higher in the large city than in the rural area. The regression of land price on the land-use zone shows that $\mathrm{R}^{2}$ is 0.76 for Gangnam-gu, compared to 0.55 for Jangseong-gun.

This means that the land use planning factor (land-use zone) accounts for $76 \%$ of land price in Gangnam-gu, and about 55\% in Jangseong-gun. When the land use of individual lands are added, $\mathrm{R}^{2}$ rises to 0.92 and 0.89 , respectively; and thus the analysis shows that the land-use zone and the land uses determine around $90 \%$ of land price. When road conditions are added, $\mathrm{R}^{2}$ improves by 0.03 in Gangnam-gu and 0.02 in Jangseong-gun, respectively. Even when land form, height, and direction are included, the overall effects of improvement in $\mathrm{R}^{2}$ is insignificant 0.03 or so.

The road conditions are a variable that has great effects on land price, but are partially included in land uses, and thus multicollinearity occurs; and the land uses have higher influence on land price than the road conditions. Therefore, the land use can be a more appropriate factor than the road con-

Table 1 Land price determining force by land price determinant in Gangnam-gu and Jangseong-gun

\begin{tabular}{c|c|c|c|c|c|c|c|c|c|c}
\hline \multicolumn{4}{c|}{ Gangnam-gu } & \multicolumn{5}{c}{ Jangseong-gun } \\
\hline Division & $\begin{array}{c}\text { land-use } \\
\text { zone }\end{array}$ & $\begin{array}{c}\text { Land } \\
\text { use }\end{array}$ & $\begin{array}{c}\text { Road } \\
\text { adjacency }\end{array}$ & Form & Height & $\begin{array}{c}\text { land-use } \\
\text { zone }\end{array}$ & Land use & $\begin{array}{c}\text { Road } \\
\text { adjacency }\end{array}$ & Form & Height \\
\hline $\mathrm{R}^{2}$ & 0.7627 & 0.9163 & 0.9435 & 0.9463 & 0.9499 & 0.5472 & 0.8928 & 0.9055 & 0.9072 & 0.9183 \\
\hline $\mathrm{R}^{2}$ (increment) & - & 0.15 & 0.03 & 0.003 & 0.004 & - & 0.35 & 0.02 & 0.002 & 0.01 \\
\hline
\end{tabular}


Table 2 Class intervals for HLPAs classification (illustration)

(Unit: KRW 10,000/m²)

\begin{tabular}{|c|c|c|c|c|c|c|c|c|c|c|c|c|c|c|c|c|}
\hline \multicolumn{2}{|c|}{ land-use zone Use status } & \multicolumn{3}{|c|}{ Residential } & \multicolumn{3}{|c|}{ Commercial } & \multicolumn{3}{|c|}{$\begin{array}{c}\text { Agricultural } \\
\text { (fields and paddies) }\end{array}$} & \multicolumn{3}{|c|}{ Industrial } & \multicolumn{3}{|c|}{ Forest land } \\
\hline City or gun & Area & $\begin{array}{c}\text { Large } \\
\text { city }\end{array}$ & $\begin{array}{l}\text { S\&M } \\
\text { city }\end{array}$ & $\begin{array}{c}\text { Gun } \\
\text { region }\end{array}$ & $\begin{array}{l}\text { Large } \\
\text { city }\end{array}$ & $\begin{array}{l}\text { S\&M } \\
\text { city }\end{array}$ & $\begin{array}{l}\text { Gun } \\
\text { region }\end{array}$ & $\begin{array}{l}\text { Large } \\
\text { city }\end{array}$ & $\begin{array}{l}\text { S\&M } \\
\text { city }\end{array}$ & $\begin{array}{c}\text { Gun } \\
\text { region }\end{array}$ & $\begin{array}{l}\text { Large } \\
\text { city }\end{array}$ & $\begin{array}{l}\text { S\&M } \\
\text { city }\end{array}$ & $\begin{array}{l}\text { Gun } \\
\text { region }\end{array}$ & $\begin{array}{l}\text { Large } \\
\text { city }\end{array}$ & $\begin{array}{l}\text { S\&M } \\
\text { city }\end{array}$ & $\begin{array}{c}\text { Gun } \\
\text { region }\end{array}$ \\
\hline \multirow{5}{*}{$\begin{array}{l}\text { Price area in } \\
\text { residential area }\end{array}$} & 1 & 15 & 1.5 & 1.5 & 30 & 3.0 & 1.5 & 3.0 & 1.5 & 0.6 & 3.0 & 1.5 & 0.3 & 1.5 & 0.6 & 0.2 \\
\hline & 2 & 30 & 3.0 & 3.0 & 60 & 6.0 & 3.0 & 6.0 & 3.0 & 1.2 & 6.0 & 3.0 & 0.6 & 3.0 & 1.2 & 0.4 \\
\hline & 3 & 45 & 4.5 & 4.5 & 90 & 9.0 & 4.5 & 9.0 & 4.5 & 1.8 & 9.0 & 4.5 & 0.9 & 4.5 & 1.8 & 0.6 \\
\hline & 4 & 60 & 6.0 & 6.0 & 120 & 12.0 & 6.0 & 12.0 & 6.0 & 2.4 & 12.0 & 6.0 & 1.2 & 6.0 & 2.4 & 0.8 \\
\hline & $\vdots$ & $\vdots$ & $\vdots$ & $\vdots$ & $\vdots$ & $\vdots$ & $\vdots$ & $\vdots$ & $\vdots$ & $\vdots$ & $\vdots$ & $\vdots$ & $\vdots$ & $\vdots$ & $\vdots$ & $\vdots$ \\
\hline \multirow{5}{*}{$\begin{array}{l}\text { Price area in } \\
\text { commercial area }\end{array}$} & 1 & 15 & 1.5 & 1.5 & 30 & 15 & 1.5 & 3.0 & 1.5 & 0.6 & 3.0 & 1.5 & 0.3 & 1.5 & 0.6 & 0.2 \\
\hline & 2 & 30 & 3.0 & 3.0 & 60 & 30 & 3.0 & 6.0 & 3.0 & 1.2 & 6.0 & 3.0 & 0.6 & 3.0 & 1.2 & 0.4 \\
\hline & 3 & 45 & 4.5 & 4.5 & 90 & 45 & 4.5 & 9.0 & 4.5 & 1.8 & 9.0 & 4.5 & 0.9 & 4.5 & 1.8 & 0.6 \\
\hline & 4 & 60 & 6.0 & 6.0 & 120 & 60 & 6.0 & 12.0 & 6.0 & 2.4 & 12.0 & 6.0 & 1.2 & 6.0 & 2.4 & 0.8 \\
\hline & $\vdots$ & $\vdots$ & $\vdots$ & $\vdots$ & $\vdots$ & $\vdots$ & $\vdots$ & $\vdots$ & $\vdots$ & $\vdots$ & $\vdots$ & $\vdots$ & $\vdots$ & $\vdots$ & $\vdots$ & $\vdots$ \\
\hline \multirow{5}{*}{$\begin{array}{l}\text { Price area in } \\
\text { industrial area }\end{array}$} & 1 & 1.5 & 1.5 & 0.3 & 15 & 1.5 & 0.3 & 1.5 & 0.2 & 0.3 & 1.5 & 1.5 & 0.3 & 1.5 & 0.2 & 0.2 \\
\hline & 2 & 3.0 & 3.0 & 0.6 & 30 & 3.0 & 0.6 & 3.0 & 0.4 & 0.6 & 3.0 & 3.0 & 0.6 & 3.0 & 0.4 & 0.4 \\
\hline & 3 & 4.5 & 4.5 & 0.9 & 45 & 4.5 & 0.9 & 4.5 & 0.6 & 0.9 & 4.5 & 4.5 & 0.9 & 4.5 & 0.6 & 0.6 \\
\hline & 4 & 6.0 & 6.0 & 1.2 & 60 & 6.0 & 1.2 & 6.0 & 0.8 & 1.2 & 6.0 & 6.0 & 1.2 & 6.0 & 0.8 & 0.8 \\
\hline & $\vdots$ & $\vdots$ & $\vdots$ & $\vdots$ & $\vdots$ & $\vdots$ & $\vdots$ & $\vdots$ & $\vdots$ & $\vdots$ & $\vdots$ & $\vdots$ & $\vdots$ & $\vdots$ & $\vdots$ & $\vdots$ \\
\hline \multirow{5}{*}{$\begin{array}{l}\text { Price area in } \\
\text { green area }\end{array}$} & 1 & 1.5 & 1.5 & 0.3 & 3 & 1.5 & 0.3 & 1.5 & 0.6 & 0.3 & 1.5 & 1.5 & 0.3 & 0.6 & 0.2 & 0.2 \\
\hline & 2 & 3 & 3 & 0.6 & 6 & 3 & 0.6 & 3 & 1.2 & 0.6 & 3 & 3 & 0.6 & 1.2 & 0.4 & 0.4 \\
\hline & 3 & 4.5 & 4.5 & 0.9 & 9 & 4.5 & 0.9 & 4.5 & 1.8 & 0.9 & 4.5 & 4.5 & 0.9 & 1.8 & 0.6 & 0.6 \\
\hline & 4 & 6 & 6 & 1.2 & 12 & 6 & 1.2 & 6 & 2.4 & 1.2 & 6 & 6 & 1.2 & 2.4 & 0.8 & 0.8 \\
\hline & $\vdots$ & $\vdots$ & $\vdots$ & $\vdots$ & $\vdots$ & $\vdots$ & $\vdots$ & $\vdots$ & $\vdots$ & $\vdots$ & $\vdots$ & $\vdots$ & $\vdots$ & $\vdots$ & $\vdots$ & $\vdots$ \\
\hline \multirow{5}{*}{$\begin{array}{l}\text { Price area in } \\
\text { control area }\end{array}$} & 1 & 1.5 & 1.5 & 0.3 & 3 & 1.5 & 1.5 & 1.5 & 0.6 & 0.3 & .5 & 1.5 & 0.3 & 0.6 & 0.2 & 0.2 \\
\hline & 2 & 3 & 3 & 0.6 & 6 & 3 & 3 & 3 & 1.2 & 0.6 & 3 & 3 & 0.6 & 1.2 & 0.4 & 0.4 \\
\hline & 3 & 4.5 & 4.5 & 0.9 & 9 & 4.5 & 4.5 & 4.5 & 1.8 & 0.9 & 4.5 & 4.5 & 0.9 & 1.8 & 0.6 & 0.6 \\
\hline & 4 & 6 & 6 & 1.2 & 12 & 6 & 6 & 6 & 2.4 & 1.2 & 6 & 6 & 1.2 & 2.4 & 0.8 & 0.8 \\
\hline & $\vdots$ & $\vdots$ & $\vdots$ & $\vdots$ & $\vdots$ & $\vdots$ & $\vdots$ & $\vdots$ & $\vdots$ & $\vdots$ & $\vdots$ & $\vdots$ & $\vdots$ & $\vdots$ & $\vdots$ & $\vdots$ \\
\hline \multirow{5}{*}{$\begin{array}{l}\text { Price area in } \\
\text { agricultural and } \\
\text { forest area }\end{array}$} & 1 & 1.5 & 0.6 & 0.3 & 1.5 & 0.6 & 0.3 & 1.5 & 0.2 & 0.2 & 1.5 & 0.6 & 0.3 & 1.5 & 0.2 & 0.2 \\
\hline & 2 & 3 & 1.2 & 0.6 & 3 & 1.2 & 0.6 & 3 & 0.4 & 0.4 & 3 & 1.2 & 0.6 & 3 & 0.4 & 0.4 \\
\hline & 3 & 4.5 & 1.8 & 0.9 & 4.5 & 1.8 & 0.9 & 4.5 & 0.6 & 0.6 & 4.5 & 1.8 & 0.9 & 4.5 & 0.6 & 0.6 \\
\hline & 4 & 6 & 2.4 & 1.2 & 6 & 2.4 & 1.2 & 6 & 0.8 & 0.8 & 6 & 2.4 & 1.2 & 6 & 0.8 & 0.8 \\
\hline & $\vdots$ & $\vdots$ & $\vdots$ & $\vdots$ & $\vdots$ & $\vdots$ & $\vdots$ & $\vdots$ & $\vdots$ & $\vdots$ & $\vdots$ & $\vdots$ & $\vdots$ & $\vdots$ & $\vdots$ & $\vdots$ \\
\hline \multirow{5}{*}{$\begin{array}{l}\text { Price area in } \\
\text { nature } \\
\text { conservation } \\
\text { area }\end{array}$} & 1 & 1.5 & 0.6 & 1.5 & 1.5 & 0.6 & 0.6 & 1.5 & 0.2 & 0.2 & 0.2 & 0.6 & 0.3 & 1.5 & 0.2 & 0.2 \\
\hline & 2 & 3 & 1.2 & 3 & 3 & 1.2 & 1.2 & 3 & 0.4 & 0.4 & 0.4 & 1.2 & 0.6 & 3 & 0.4 & 0.4 \\
\hline & 3 & 4.5 & 1.8 & 4.5 & 4.5 & 1.8 & 1.8 & 4.5 & 0.6 & 0.6 & 0.6 & 1.8 & 0.9 & 4.5 & 0.6 & 0.6 \\
\hline & 4 & 6 & 2.4 & 6 & 6 & 2.4 & 2.4 & 6 & 0.8 & 0.8 & 0.8 & 2.4 & 1.2 & 6 & 0.8 & 0.8 \\
\hline & $\vdots$ & $\vdots$ & $\vdots$ & $\vdots$ & $\vdots$ & $\vdots$ & $\vdots$ & $\vdots$ & $\vdots$ & $\vdots$ & $\vdots$ & $\vdots$ & $\vdots$ & $\vdots$ & $\vdots$ & $\vdots$ \\
\hline
\end{tabular}

Note: These class intervals of HLPAs illustrate basic class intervals.

8 Journal of Real Estate Analysis Vol.1, No.1 (December, 2015) 
ditions in the classification of the HLPAs.

Consequently, the primary HLPAs are classified according to administrative district, land-use zones, and land uses. And the influence of the remaining land price determinants (the school district, and accessibility to a park or the nimby facilities such as a garbage disposal plant), which show local amenities, can be reflected with the price scale of the land price index table.

The next step for classifying HLPAs is to stratify land price levels according to key land price determinants in the administrative district. Class intervals for land price strata that classify HLPAs are illustrated in Table 2. The class intervals can be sub-divided into class intervals for sub-strata according to the levels of local land price. Based on this HLPAs, standard lots can be allocated and selected evenly from the diverse price levels.

\section{2) Adjustments to the HLPAs}

The adequacy of the HLPAs depends on the accuracy of basic data. Survey errors on land characteristics or price may distort the HLPAs. Therefore, it is necessary to supplement and adjust the HLPAs at fixed periods in order to enhance the adequacy of and sophisticate HLPAs classification.

Once the HLPAs classification has been somewhat stabilized, the HLPAs should be adjusted every 3 or 5 years. But in case that any factor of local price variation occurs such as a large scale development project and a change in the land-use zone, the HLPAs should be adjusted whenever necessary. At an early stage, the HLPAs classification is carried out at the level of the local administration; after the HLPAs classification is fully completed, however, it can be operated at the integrated level of metro \& province level.

3) The method for the assessment of land price, using the HLPAs

The officially announced land price is assessed using market data according to the sales comparison approach. However, the standard lot is difficult to appraise if there is no similar transaction case in the neighborhood.

In case that HLPAs have been classified, sale cases within the same HLPAs can be identified even though the lands are spatially separated. If there is no comparative standard lot (or market price) of similar characteristics in the neighborhood, the comparative standard lot (or market price) may be selected from other HLPA, and land price can be calculated by adjusting price differences between the HLPAs.

The example in Table 3 is an illustration of a way to use the HLPAs. In case of calculating the value of lot No. 20, as shown in Table 3, an HLPA for the lot is identified 
Table 3 The selection of comparative standard lot and transacted market price and the calculation of price, using the HLPAs (example)

\begin{tabular}{|c|c|c|c|c|c|c|c|}
\hline & \multirow[b]{2}{*}{ Lot No. } & \multicolumn{4}{|c|}{ HLPAs } & \multirow[b]{2}{*}{$\begin{array}{c}\text { Market } \\
\text { price } \\
(\mathrm{KRW})\end{array}$} & \multirow[b]{2}{*}{$\begin{array}{c}\text { Price } \\
\text { adjustment } \\
\text { (KRW) }\end{array}$} \\
\hline & & No. & $\begin{array}{c}\text { Class } \\
\text { interval } \\
(\mathrm{KRW})\end{array}$ & $\begin{array}{c}\text { Distance } \\
(\mathrm{km})\end{array}$ & $\begin{array}{c}\text { Date of } \\
\text { transaction }\end{array}$ & & \\
\hline $\begin{array}{l}\text { Lot subject to } \\
\text { assessment }\end{array}$ & 20, $x \bigcirc \bigcirc$-ri, B-myeon, A-gun & 5 & 140,000 & - & & & \\
\hline $\begin{array}{l}\text { Case (1) of real } \\
\text { transaction }\end{array}$ & 15, $x \bigcirc \bigcirc-$-ri, C-myeon, A-gun & 5 & 140,000 & 1.2 & '15.5 & 130,000 & \\
\hline $\begin{array}{l}\text { Case (2) of real } \\
\text { transaction }\end{array}$ & 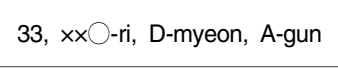 & 4 & 130,000 & 1.5 & '15.2 & 135,000 & $+10,000$ \\
\hline $\begin{array}{l}\text { Case (3) of real } \\
\text { transaction }\end{array}$ & 200, xxx-ri, E-myeon, A-gun & 6 & 150,000 & 2.1 & $' 14.10$ & 153,000 & $-10,000$ \\
\hline $\begin{array}{l}\text { Case (4) of real } \\
\text { transaction }\end{array}$ & 310, xxx-ri, E-myeon, A-gun & 6 & 150,000 & 3.0 & 14.3 & 159,000 & $-10,000$ \\
\hline
\end{tabular}

first. The lot to be assessed belongs to HLPA No. 5. If there is no market transaction case belonging to the HLPA No. 5 in the same region (ri), the land price can be calculated by applying price differences due to differences in lot characteristics on the basis of the market price of land No. (1) sold at other region belonging to the HLPA No. 5 .

When there is no transaction case of the same HLPA, price adjustment is carried out by adding or subtracting a class interval between HLPAs on the basis of transaction cases (2), (3), and (4) belonging to other HLPAs. That is, in case of using the market price of case (2) belonging to HLPA No. 4, adjustment is made by adding KRW 10,000, for the HLPA No. 4 is lower by one class interval. And in case of using the market price of land case (3), which is higher by one class interval, adjustment is made by subtracting KRW 10,000.

On this wise, assessment adjustment re- garding regional differences is made by making adjustment for the class interval between HLPAs, and then the land price can be calculated by applying a price scale in the land price index table according to differences in characteristics such as road conditions and geographical feature. In addition, as for the transaction case by HLPA, the most recent transaction case or the nearest transaction case in the neighborhood can be selected preferentially; and in case of a long time lag, time adjustment should be made by applying the change rate of land price.

In the assessment of individual land prices as well as standard lot price, the HLPAs can enhance rationality in the selection of a comparative standard lot, for the comparative standard lot can also be selected through the same process. Therefore, the HLPAs can enhance the closeness of assessed land price to the market price consistently. 


\section{Case studies}

\section{Target regions}

One large city region and one gun region, which allow the analysis of urban and non-urban regions' characteristics, are selected as case regions. As a case of large city region, Gangnam-gu was selected, and as a case of gun region, Jangseong-gun in Jeollanam-do was selected.

Gangnam-gu, Seoul, has an area of 39.51 $\mathrm{km}^{2}$, which accounts for $6.53 \%$ of the whole area of Seoul Metropolitan City, and consists of 22 administrative dongs (14 legal dongs). The number of lots in Gangnam-gu is a total of $56,112,81.9 \%$ of which belong to Residential Zones. The number of standard lots are 1,134 lots, which represent $2 \%$ of the total number of lots; and among the standard lots, $77.7 \%$ are distributed in Residential Zones, $13.5 \%$ in Commercial Zones and 5.9\% in Development Restriction Zones, respectively. Jangseong-gun, Jeollanam-do, has an area of about $518.3 \mathrm{~km}^{2}$, and consists of one eup, 10 myeons, and 292 ris, among which Bukhaeup has the widest area of $84 \mathrm{~km}^{2}$. Jangseonggun has forest land of about $319.79 \mathrm{~km}^{2}$, which accounts for the largest portion of the whole area of Jangseong-gun, followed by paddies of $16 \%$ and fields of $7 \%$. As for standard lots, $2,495,1.8 \%$ of the total lots, are dis-

Table 4 Distribution of Standard Lots in Gangnam-gu and Jangseong-gun

\begin{tabular}{c|cc|c|c|c|c|c|c|c}
\hline \multicolumn{2}{l}{ (Unit: lot) } \\
\hline
\end{tabular}

Note: ( ) indicates the number of individual lots. 
tributed across the gun, with about $41 \%$ being distributed in Management Zones and 24\% in Green Zones in terms of the land-use zone.

\section{Basic data1)}

As basic data for the classification of HLPAs, officially assessed individual land prices are used. Although officially assessed individual land prices have the disadvantages that they show the low ratio of assessed values to market values and that the ratio of assessed values to market values varies with regions, they are the sole data that provide price data and land characteristics data on all lands except some state-owned and publicly owned lands.

To solve the problem of the low ratio of assessed prices to market prices, this paper derived the ratios of assessed prices to market prices by the land-use zone and the land use, on the basis of 2014 assessed prices and market price data for 2011 to 2014; and readjusted assessed prices of individual lands to market prices by applying the ratios, and also made adjustment for time lags by applying the land price change rates during the periods. In addition, for diagram information employed in GIS spatial analysis in order to represent HLPAs, June 2014 data that reflected the modification of administrative districts were used.

\section{Illustration of HLPAs classification}

1) Distribution of land price levels

As a result of examining the land-use zones and land uses of Gangnam-gu in order

Table 5 Land price levels in Gangnam-gu and Jangseong-gun

\begin{tabular}{|c|c|c|c|c|c|c|c|c|}
\hline \multicolumn{2}{|c|}{ Land use } & $\begin{array}{l}\text { Land use } \\
\text { Zone }\end{array}$ & $\begin{array}{c}\text { Number } \\
\text { of lots }\end{array}$ & Mean (KRW) & S.D. (KRW) & $\begin{array}{l}\text { Minimum } \\
(\mathrm{KRW})\end{array}$ & $\begin{array}{l}\text { Maximum } \\
(\mathrm{KRW})\end{array}$ & $\begin{array}{l}\text { Median } \\
(\mathrm{KRW})\end{array}$ \\
\hline \multirow{4}{*}{ 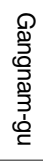 } & \multirow{4}{*}{ 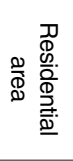 } & Residential & 11,475 & $8,124,529$ & $2,734,437$ & $2,149,500$ & $23,430,400$ & $7,823,475$ \\
\hline & & Commercial & 8,169 & $17,501,142$ & $8,684,070$ & $3,267,628$ & $59,625,000$ & $15,763,500$ \\
\hline & & Forest land & 132 & $1,008,437$ & 689,095 & 659,753 & $5,292,560$ & 763,350 \\
\hline & & Agricultural & 14 & $2,491,021$ & 357,956 & $1,704,795$ & $2,980,496$ & $2,625,024$ \\
\hline \multirow{8}{*}{ 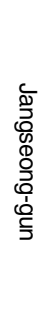 } & \multirow{4}{*}{ 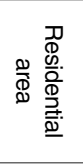 } & Residential & 9,342 & 148,138 & 85,532 & 17,979 & 756,694 & 128,408 \\
\hline & & Commercial & 137 & 420,980 & 309,238 & 77,249 & $2,741,024$ & 388,192 \\
\hline & & Forest land & 242 & 34,522 & 13,738 & 2,899 & 55,604 & 40,142 \\
\hline & & Agricultural & 984 & 60,256 & 32,795 & 13,067 & 214,118 & 58,176 \\
\hline & \multirow{4}{*}{ 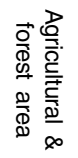 } & Residential & 717 & 26,524 & 12,332 & 6,750 & 84,739 & 22,671 \\
\hline & & Commercial & 14 & 48,828 & 54,599 & 31,077 & 237,538 & 31,802 \\
\hline & & Forest land & 8,688 & 2,454 & 1,711 & 356 & 16,947 & 2,155 \\
\hline & & Agricultural & 26,456 & 15,835 & 4,870 & 2,147 & 60,830 & 15,271 \\
\hline
\end{tabular}

1) For the basic data of this paper, data in Kim Bong-joon et al. (2015) were used. 
to classify its HLPAs, it was found that its land-use zones consisted of Commercial Zone, Residential Zone (Type 1, Type 2, and Type 3), and Green Zone (Natural Green Zone, Production Green Zone, and Preservation Green Zone), and that as for the land uses, the distribution of housing land, shops and offices, factory, agricultural land (fields and paddies), and forest land varied with land-use zones. Jangseong-gun included 7 land-use zones and 6 land uses. Among analytic data on land-use zones and land uses in the two regions, the distribution of land price levels for the Residential Zone of Gangnam-gu and for the Agricultural and Forest Zone of Jangseong-gun is as shown in Table 5.

2) Illustration of HLPAs classification As HLPAs are classified according to detailed land-use zones, a number of HLPAs are created. Therefore, on account of space considerations, this paper will present cases

Table 6 An illustration of HLPAs classification for residential use within General Residential Zone Type 2 in Gangnam-gu, and the distribution of standard lots

\begin{tabular}{|c|c|c|c|c|c|}
\hline $\begin{array}{c}\text { Price area } \\
(\text { KRW 10,000) }\end{array}$ & Number of lot(s) & $\begin{array}{c}\text { Number of } \\
\text { standard lot(s) }\end{array}$ & $\begin{array}{c}\text { Price area } \\
(\text { KRW 10,000) }\end{array}$ & Number of lot(s) & $\begin{array}{c}\text { Number of } \\
\text { standard lot(s) }\end{array}$ \\
\hline Area $10(135 \sim 150)$ & 1 & $-(1)$ & Area 32 (465 480) & 261 & $8(1)$ \\
\hline Area $11(150 \sim 165)$ & 3 & $-(1)$ & Area 33 (480 495) & 191 & $6(1)$ \\
\hline Area $12(165 \sim 180)$ & 28 & $-(1)$ & Area 34 (495 510) & 162 & $6(1)$ \\
\hline Area $13(180 \sim 195)$ & 363 & $13(1)$ & Area 35 (510 525) & 93 & $6(1)$ \\
\hline Area 14 (195 210) & 298 & $9(1)$ & Area $36(525 \sim 540)$ & 61 & $2(1)$ \\
\hline Area 15 (210 225) & 234 & $2(1)$ & Area 37 (540 555) & 70 & $2(1)$ \\
\hline Area 16 (225 240) & 500 & $9(1)$ & Area 38 (555 570) & 37 & $2(1)$ \\
\hline Area 17 (240 255) & 598 & $19(1)$ & Area 39 (570 585) & 18 & $-(1)$ \\
\hline Area 18 (255 270) & 441 & 12(1) & Area 40 (585 600) & 13 & $-(1)$ \\
\hline Area 19 (270 285) & 403 & 21(1) & Area 41 (600 615) & 14 & $-(1)$ \\
\hline Area $20(285 \sim 300)$ & 297 & $9(1)$ & Area 42 (615 630) & 23 & $-(1)$ \\
\hline Area $21(300 \sim 315)$ & 147 & $3(1)$ & Area 44 (645 660) & 1 & $-(1)$ \\
\hline Area $22(315 \sim 330)$ & 185 & $7(1)$ & Area 45 (660 675) & 1 & $-(1)$ \\
\hline Area $23(330 \sim 345)$ & 406 & $13(1)$ & Area 48 (705 720) & 12 & $-(1)$ \\
\hline Area $24(345 \sim 360)$ & 176 & $5(1)$ & Area $49(720 \sim 735)$ & 3 & 1(1) \\
\hline Area 25 (360 375) & 186 & $3(1)$ & Area $50(735 \sim 750)$ & 1 & $-(1)$ \\
\hline Area 26 (375 390) & 127 & $5(1)$ & Area 52 (765 780) & 1 & $-(1)$ \\
\hline Area $27(390 \sim 405)$ & 110 & $2(1)$ & Area $54(795 \sim 810)$ & 1 & $-(1)$ \\
\hline Area $28(405 \sim 420)$ & 148 & $2(1)$ & Area 55 (810 825) & 3 & $-(1)$ \\
\hline Area $29(420 \sim 435)$ & 334 & $8(1)$ & Area 57 (840 855) & 1 & $-(1)$ \\
\hline Area $30(435 \sim 450)$ & 267 & $6(1)$ & Area 58 (855 870) & 1 & $-(1)$ \\
\hline Area 31 (450 465) & 321 & $12(1)$ & 43 areas in total & & \\
\hline
\end{tabular}

Note: ( ) shows examples of standard lot allocation by HLPAs. 
of analyzing HLPAs of residential use within the General Residential Zone Type 2 in the case of Gangnam-gu, and the General Residential Zone Type 1 and HLPAs of paddy land within the Agricultural and Forest Zone in the case of Jangseong-gun.

HLPAs for the General Residential Zone Type 2 of Gangnam-gu were classified at a class interval of KRW $150,000 / \mathrm{m}^{2}$. In this case, there is no lot falling under HLPAs No. 1 to No. 9, as shown in Table 6, and its HLPAs consist of a total of 43 between No. 10 and No. 58. To examine the distribution of lots by HLPA, 234 lots belong to HLPA No. 15, 500 lots to HLPA No. 16, and 598 lots to HLPA No. 17. On the other hand, one lot belongs to each of seven areas including HLPA No.10 (below KRW 1.5 million/ $\mathrm{m}^{2}$ ) and HLPA No. 44 (KRW 6.45 million or more $\left./ \mathrm{m}^{2}\right)$. This implies that in price areas of complicated and unusual price distribution, HLPAs are divided only with a small number of lots, while in areas of homogeneous and equalized price distribution, a large number of lots are classified into a single price area.

HLPAs are classified by computer, and thus it does not matter whether a many or small number of lots belong to one HLPA. In case of psychological objection to a different administrative district, an additional standard lot may be selected through the division of administrative district or block, which, however, is not very significant. In the case of HLPAs having a small number of lots below 10 lots, they are cases of unusual land price levels or land characteristics, and thus one standard lot is selected for each of them. But in the case of a price area to which only one lot belongs, it may be due to an error in land characteristics, which should be checked; in case of an error, the lot should be regrouped in its relevant HLPA, and in case of an unusual price, the lot should be selected as a standard lot to maintain the price area as a separate single HLPA, even though there is only one lot in it.

On the other hand, the land price distribution of Jangseong-gun is very simple. Residential lands within the General Residential Zone Type 1 are classified into 25 HLPAs with the class interval of KRW $15,000 / \mathrm{m}^{2}$; and paddies within the Agriculture and Forest Zone are classified into 21 HLPAs with the class interval of KRW 2,000/ $\mathrm{m}^{2}$. In the case of residential lands within the General Residential Zone Type 1, 1,302 lots are included in HLPA No. 7, and a small number of lots belong to HLPA No. 23 and above, which are KRW 330,000/ $\mathrm{m}^{2}$ or higher. In the case of HLPAs for paddies within the Agricultural and Forest Zone, $88.5 \%$ of lots belong to KRW 10,000/ $\mathrm{m}^{2}$ to KRW 20,000/ $\mathrm{m}^{2}$, whereas $5.8 \%$ is distributed in HLPAs below KRW $10,000 / \mathrm{m}^{2}$. There are eight lots in 
the HLPA below KRW $4,000 / \mathrm{m}^{2}$, and five lots in four HLPAs above KRW 36,000/ $\mathrm{m}^{2}$. As for lots in HLPAs above KRW 36,000/ $\mathrm{m}^{2}$, among HLPAs for paddies within the Agricultural and Forest Zone, it should be checked whether there is any error in the land characteristics survey or the land price; and adjustment to HLPAs should be made, if necessary. And if not being an error, the HLPAs should be maintained as single price areas, and their lots should be selected as standard lots. This classification of HLPAs also has the additional advantage that error in land characteristics or land price calcu-

Table 7 Examples of the HLPAs, and standard lot distribution (General Residential Zone Type 1-residential and Agricultural and Forest Zone-paddies)

\begin{tabular}{|c|c|c|c|c|c|c|c|c|c|}
\hline $\begin{array}{l}\text { land- } \\
\text { use } \\
\text { zone }\end{array}$ & $\begin{array}{l}\text { Land } \\
\text { use }\end{array}$ & $\begin{array}{c}\text { Price area } \\
(\text { KRW 10,000) }\end{array}$ & $\begin{array}{c}\text { Number of } \\
\operatorname{lot}(\mathrm{s})\end{array}$ & $\begin{array}{c}\text { Number of } \\
\text { standard lot(s) }\end{array}$ & $\begin{array}{c}\text { land- } \\
\text { use } \\
\text { zone }\end{array}$ & $\begin{array}{c}\text { Land } \\
\text { use }\end{array}$ & $\begin{array}{c}\text { Price area } \\
\text { (KRW 10,000) }\end{array}$ & $\begin{array}{l}\text { Number of } \\
\text { lot(s) }\end{array}$ & $\begin{array}{c}\text { Number of } \\
\text { standard lot(s) }\end{array}$ \\
\hline \multirow{26}{*}{ 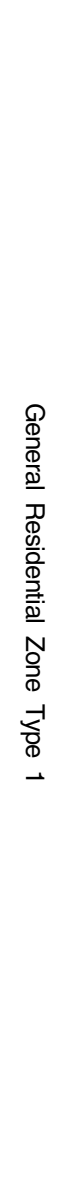 } & \multirow{26}{*}{ 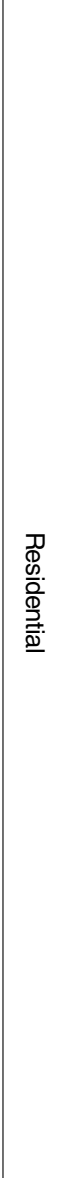 } & Area $2(1.5-3.0)$ & 49 & $2(1)$ & \multirow{26}{*}{ 党 } & \multirow{26}{*}{ 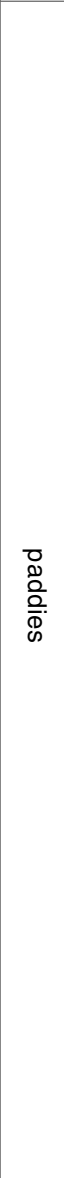 } & Area $2(0.2-0.4)$ & 9 & $-(1)$ \\
\hline & & Area $3(3.0-4.5)$ & 708 & 14(1) & & & Area $3(0.4-0.6)$ & 75 & $1(1)$ \\
\hline & & Area $4(4.5-6.0)$ & 1,337 & $22(1)$ & & & Area 4 (0.6-0.8) & 278 & $3(1)$ \\
\hline & & Area 5 (6.0-7.5) & 622 & $13(1)$ & & & Area 5 (0.8-1.0) & 921 & $8(1)$ \\
\hline & & Area 6 (7.5-9.0) & 897 & $13(1)$ & & & Area 6 (1.0-1.2) & 1,371 & $23(1)$ \\
\hline & & Area 7 (9.0-10.5) & 1,302 & $28(1)$ & & & Area 7 (1.2-1.4) & 4,901 & $75(1)$ \\
\hline & & Area $8(10.5-12.0)$ & 751 & $12(1)$ & & & Area 8 (1.4-1.6) & 7,484 & $120(1)$ \\
\hline & & Area 9 (12.0-13.5) & 600 & $7(1)$ & & & Area 9 (1.6-1.8) & 3,630 & $45(1)$ \\
\hline & & Area $10(13.5-15.0)$ & 571 & $9(1)$ & & & Area $10(1.8-2.0)$ & 2,050 & $31(1)$ \\
\hline & & Area 11 (15.0-16.5) & 395 & $6(1)$ & & & Area $11(2.0-2.2)$ & 502 & $2(1)$ \\
\hline & & Area $12(16.5-18.0)$ & 232 & $12(1)$ & & & Area $12(2.2-2.4)$ & 334 & $7(1)$ \\
\hline & & Area $13(18.0-19.5)$ & 118 & $1(1)$ & & & Area $13(2.4-2.6)$ & 128 & $2(1)$ \\
\hline & & Area $14(19.5-21.0)$ & 101 & $5(1)$ & & & Area 14 (2.6-2.8) & 119 & $-(1)$ \\
\hline & & Area $15(21.0-22.5)$ & 99 & $2(1)$ & & & Area $15(2.8-3.0)$ & 78 & $1(1)$ \\
\hline & & Area $16(22.5-24.0)$ & 42 & $-(1)$ & & & Area 16 (3.0-3.2) & 19 & $-(1)$ \\
\hline & & Area $17(24.0-25.5)$ & 64 & $1(1)$ & & & Area 17 (3.2-3.4) & 30 & $-(1)$ \\
\hline & & Area $18(25.5-27.0)$ & 21 & 1(1) & & & Area 18 (3.4-3.6) & 34 & $-(1)$ \\
\hline & & Area $19(27.0-28.5)$ & 25 & 1(1) & & & Area 19 (3.6-3.8) & 1 & $-(1)$ \\
\hline & & Area $20(28.5-30.0)$ & 31 & $-(1)$ & & & Area $20(3.8-4.0)$ & 1 & $-(1)$ \\
\hline & & Area $21(30.0-31.5)$ & 33 & $1(1)$ & & & Area $21(4.0-4.2)$ & 2 & $-(1)$ \\
\hline & & Area $22(31.5-33.0)$ & 16 & $-(1)$ & & & Area $25(4.8-5.0)$ & 1 & $-(1)$ \\
\hline & & Area $23(33.0-34.5)$ & 2 & $2(1)$ & & & - & - & - \\
\hline & & Area $24(34.5-36.0)$ & 1 & $-(1)$ & & & - & - & - \\
\hline & & Area $25(36.0-37.5)$ & 1 & $-(1)$ & & & - & - & - \\
\hline & & Area $30(43.5-45.0)$ & 1 & $-(1)$ & & & - & - & - \\
\hline & & 25 areas in total & & & & & 21 areas in total & & \\
\hline
\end{tabular}

Note: ( ) shows the illustration of standard lot allocation by HLPAs. 
lation can be detected in a relatively prompt manner.

\section{Verification of the classification method of HLPAs}

\section{Method of verification}

The adequacy of the method for HLPA classification is verified in terms of the adequacy of standard lot distribution, the land price balance between lots, and the market value reflection degree. As for the method for verifying the adequacy of standard lot distribution, changes in standard lot density between current standard lot numbers and standard lot numbers based on the HLPAs are compared.

Then, as for the land price balance, changes in the scales of the land price index table, which influence the land price balance between lots, are analyzed. The land price index table by HLPA is prepared, and differences according to land characteristics in the HLPA are compared. And then, verification is conducted by comparing and analyzing land price distribution disparity between land prices calculated on the basis of the land price index table newly prepared by the HLPAs.
Land price balance between individual lots is also verified by calculating the coefficient of variation of land prices.

Lastly, the closeness to market price is verified by comparing market price data, officially assessed individual land prices, and newly calculated land prices by homogeneous area.

\section{Results of verification}

1) Verification of the efficiency of standard lot management

HLPAs classification allows the selection of a standard lot by HLPA and the even allocation of standard lots in HLPAs, which can enhance the efficiency of standard lot management and the convenience of standard lot selection.

As for an HLPA of a great difference in price level, an unusual price can be reflected by selecting one standard lot in the price area even when only one or two lots belong to the price area. And as for an HLPA where prices are equalized, price can be calculated from one standard lot even when many lots belong to the price area.

For example, as shown in Table 6, as for HLPA Nos. 15, 16, and 17, which include relatively many lots, among residential HLPAs within the General Residential Zone Type 2 in Gangnam-gu, currently 30 standard lots, 
Table 8 Allocation of standard lot(s) by HLPA (example)

\begin{tabular}{|c|c|c|c|c|c|c|c|}
\hline \multirow[t]{2}{*}{ Division } & \multirow[t]{2}{*}{$\begin{array}{l}\text { land-use zone } \\
\text { (land use) }\end{array}$} & \multirow[t]{2}{*}{$\begin{array}{c}\text { Price area } \\
(\text { KRW 10,000) }\end{array}$} & $\begin{array}{l}\text { Number } \\
\text { of lots }\end{array}$ & $\begin{array}{l}\text { Number } \\
\text { of current } \\
\text { standard } \\
\text { lots }\end{array}$ & \multirow[t]{2}{*}{$\begin{array}{l}\text { Ratio (\%) } \\
\text { (b)/(a) }\end{array}$} & $\begin{array}{c}\text { Minimum allocation } \\
\text { of standard lot(s) } \\
\text { by HLPA } \\
\text { (example) }\end{array}$ & \multirow[t]{2}{*}{$\begin{array}{c}\text { Ratio (\%) } \\
\text { (c)/(a) }\end{array}$} \\
\hline & & & (a) & (b) & & (c) & \\
\hline \multirow{4}{*}{ 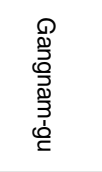 } & \multirow{4}{*}{$\begin{array}{c}\text { General } \\
\text { Residential } \\
\text { Zone Type } 2 \\
\text { (Residential) }\end{array}$} & Area 15 (210-225) & 234 & 2 & 0.009 & 1 & 0.004 \\
\hline & & Area $16(225-240)$ & 500 & 9 & 0.018 & 1 & 0.002 \\
\hline & & Area 17 (240-255) & 598 & 19 & 0.032 & 1 & 0.002 \\
\hline & & Total & 1,332 & 30 & 0.023 & 3 & 0.002 \\
\hline \multirow{6}{*}{ 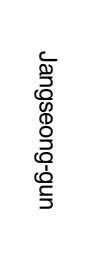 } & \multirow{3}{*}{$\begin{array}{l}\text { General } \\
\text { Residential } \\
\text { Zone Type } 1 \\
\text { (Residential) }\end{array}$} & Area $3(3.0-4.5)$ & 708 & 14 & 0.020 & 1 & 0.001 \\
\hline & & Area $4(4.5-6.0)$ & 1,337 & 22 & 0.016 & 1 & 0.001 \\
\hline & & Total & 2,045 & 36 & 0.018 & 2 & 0.001 \\
\hline & \multirow{3}{*}{$\begin{array}{l}\text { Agricultural and } \\
\text { Forest Zone } \\
\text { (Agricultural) }\end{array}$} & Area 7 (1.2-1.4) & 5,370 & 78 & 0.015 & 1 & 0.000 \\
\hline & & Area 8 (1.4-1.6) & 7,910 & 125 & 0.016 & 1 & 0.000 \\
\hline & & Total & 10,280 & 203 & 0.020 & 2 & 0.000 \\
\hline
\end{tabular}

$2.2 \%$ of the total 1,332 lots, were selected. As for HLPA Nos. 39 through No. 58 (price levels of KRW 5.7 million through KRW 8.7 million), however, there is no standard lot allocated in them. A similar phenomenon also occurs at the General Residential Zone Type 1 and the Agricultural and Forest Zone in Jangseong-gun.

Most of individual land prices newly calculated in an HLPA are distributed within a price range of the HLPA; and thus it is possible to calculate lot prices from one standard lot. Therefore, even though many lots belong to HLPA Nos. 15, 16, and 17, it is possible to calculate their prices even with minimum 3 standard lots, for the lots are similar in land characteristics and price levels. It can be seen that it is possible to calculate land prices with a considerably small number of standard lots compared with the current standard lots. It is found out that the problems of the inadequacy and inefficiency of standard lot distribution, which have been pointed out meanwhile under the current OASLP, can be greatly improved by the introduction of HLPAs (See Tables 6, 7, and 8).

2) Balance of land price

(1) Change in the scales of Land Price Index Table

In case of the analysis of HLPAs, the problem of scale differences by characteristics can be solved, for considerable price differences by land characteristics are filtered during the HLPAs classification, and remaining some influences are identified with the land price index table. To examine this, two land 
price assessment models were developed, one for the whole land-use zone (Zone-model) and the other for an HLPA with many lots (HLPA-model), and deducted land price index tables based on the coefficients of the models. Then the differences in price scales of the land price index tables and the balance of calculated prices between lots were compared. As a result, the analysis showed that $\mathrm{R}^{2}$ increased about $5 \%$ on average in the HLPA-model, compared to the Zone-model by the land-use zone and that the reliability of $t$-value by variable increased. And it was found that differences in price scales according to items such as road adjacency, form, and height are low and stable.

For reference, Fig. 3 shows graphs that depict the differences in scales by land characteristics based on the HLPA-model for residential use in General Residential Zone Type 1 (HLPA No. 4) and the Zone-model of the General Residential Zone Type 1 in Jangseong-gun.

As the HLPA-model is developed for a price area, not for the whole zone where diverse factors and land prices are distributed,

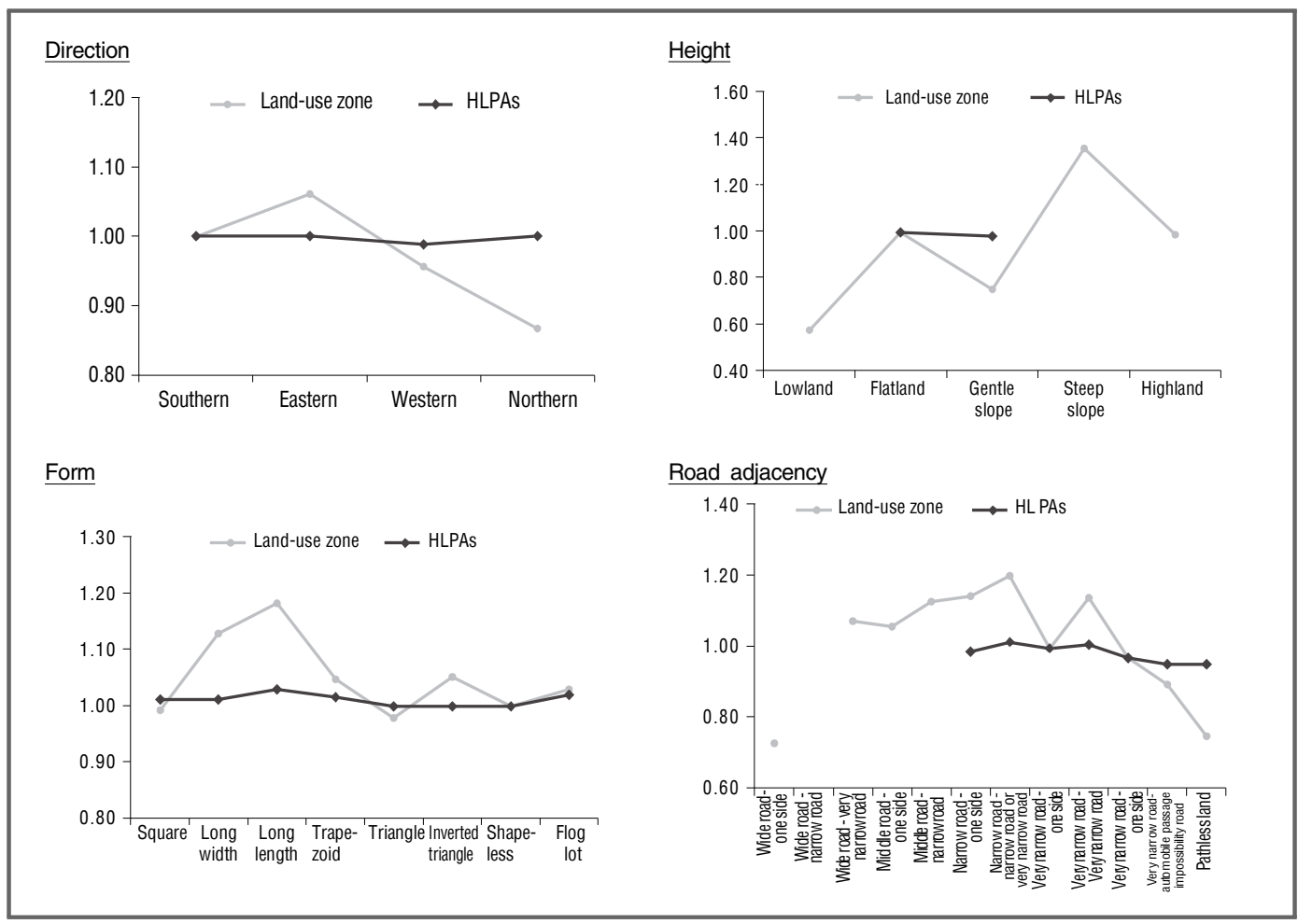

Fig. 3. Comparison of price scales between the land price index table of land-use zone and the land price index table of HLPA (Area 4, general residential area type 1 - residential, Jangseong-gun) 
only scales of land characteristics within the relevant price area are derived, and differences in scales by characteristics are also lowered greatly.

HLPA No. 4 within the General Residential Zone Type 1 in Jangseong-gun has the most lots within a single price area, and it does not show very great differences in scales for land form. In particular, it shows no great difference in price scales for direction of land, possibly because a detached house can be located towards the south even when a gate is set towards the west or the north. It implies that if HLPAs are analyzed exactly, the same characteristics can present different price scales according to the nature of HLPAs.

These differences in price scales by land characteristics can be combined by analyzing several HLPAs, grouping HLPAs showing similar scale differences, and deriving average scales.

(2) Price balance between the standard lot and the individual land

Some distributions of the current assessed land prices show great imbalance of land pri-

Table 9 Comparison of balance between the assessed standard lot price and prices of individual lots (General Residential Zone type 2 - residential use, Gangnam-gu)

\begin{tabular}{|c|c|c|c|c|c|c|}
\hline \multirow[b]{2}{*}{$\begin{array}{l}\text { Residential - } \\
\text { residential }\end{array}$} & \multicolumn{2}{|c|}{ Area 15 (KRW 2.1 2.25 mil.) } & \multicolumn{2}{|c|}{ Area 16 (KRW 2.25 2.4 mil.) } & \multicolumn{2}{|c|}{ Area 17 (KRW 2.4 2.55 mil.) } \\
\hline & $\begin{array}{c}\text { Current } \\
\text { individual land } \\
\text { price }\end{array}$ & $\begin{array}{c}\text { Calculated land } \\
\text { price by } \\
\text { homogeneous } \\
\text { area }\end{array}$ & $\begin{array}{c}\text { Current } \\
\text { individual land } \\
\text { price }\end{array}$ & $\begin{array}{c}\text { Calculated land } \\
\text { price by } \\
\text { homogeneous } \\
\text { area }\end{array}$ & $\begin{array}{c}\text { Current } \\
\text { individual land } \\
\text { price }\end{array}$ & $\begin{array}{l}\text { Calculated land } \\
\text { price by } \\
\text { homogeneous } \\
\text { area }\end{array}$ \\
\hline Over $15 \%$ & $0 \%$ & $0 \%$ & $1 \%$ & $0 \%$ & $0 \%$ & $0 \%$ \\
\hline $5 \sim 15 \%$ & $6 \%$ & $0 \%$ & $2 \%$ & $0 \%$ & $2 \%$ & $0 \%$ \\
\hline$-5 \sim 5 \%$ & $0 \%$ & $100 \%$ & $79 \%$ & $100 \%$ & $98 \%$ & $100 \%$ \\
\hline$-5 \sim-15 \%$ & $0 \%$ & $0 \%$ & $18 \%$ & $0 \%$ & $0 \%$ & $0 \%$ \\
\hline Below -15\% & $94 \%$ & $0 \%$ & $0 \%$ & $0 \%$ & $0 \%$ & $0 \%$ \\
\hline Total & $100 \%$ & $100 \%$ & $100 \%$ & $100 \%$ & $100 \%$ & $100 \%$ \\
\hline
\end{tabular}
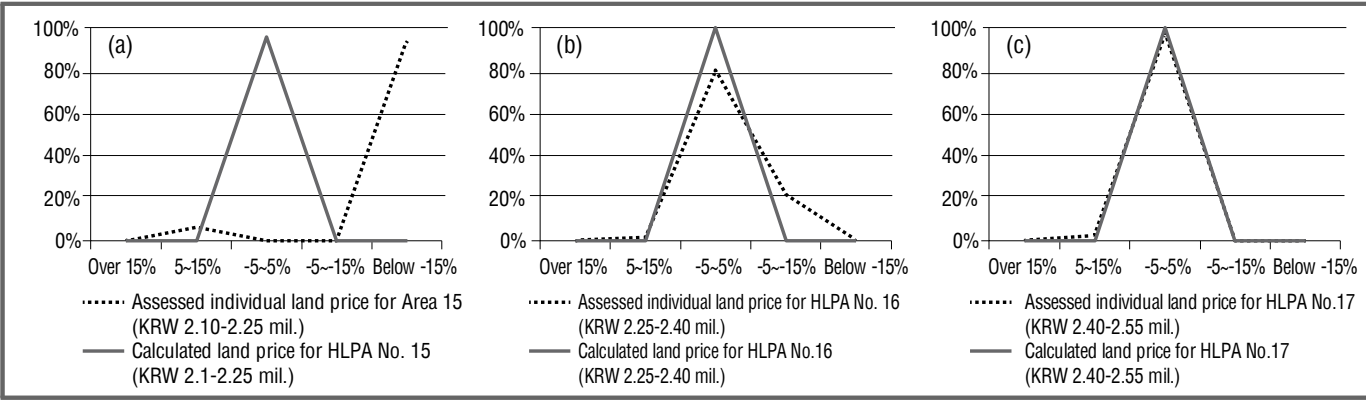

Fig. 4. Comparison of land price balance for General Residential Zone Type 2 - residential HLPAs in Gangnam-gu (a: Area 15, b: Area 16, c: Area 17) 
ces between the standard lot price and the assessed individual land prices. The imbalance of land prices is caused by three factors. First, a comparative standard lot suitable for local characteristics failed to be selected due to improper standard lot allocation. Second, scales of a land price index table by land-use zone are larger than they actually are. Third, imbalance is caused by an error in the land characteristics survey. Among them, a large portion of the first and second errors can be removed by HLPAs classification, and the third error in the land characteristics survey should be separately corrected and improved. Thus, this paper will verify how much the land price imbalance due to the first and second factors is improved by HLPAs classification.
To investigate the case of Gangnam-gu first, as a result of analyzing the rates of difference among standard lot prices, current assessed land prices (assessed price), and newly calculated land prices (calculated land price) within the General Residential Area Type 2 - residential, it was found that some current assessed prices of individual lots in HLPAs were different from standard lot prices more than $15 \%$. On the other hand, land prices calculated by HLPAs were distributed $100 \%$ within $\pm 5 \%$ from standard lot prices, and thus it was found that the price balance between the standard lot and individual lands improved noticeably.

In the case of Jangseong-gun also, as a result of analyzing price differences from standard lots in order to verify the balance

Table 10 Comparison of the land price balance between standard lot price and calculated land prices (General residential area type 1 - residential, agricultural and forest area - paddies in Jangseong-gun)

\begin{tabular}{|c|c|c|c|c|}
\hline \multirow{2}{*}{$\begin{array}{c}\text { Residential- } \\
\text { residential }\end{array}$} & \multicolumn{2}{|c|}{ Area 3 (KRW 30 45 thousand) } & \multicolumn{2}{|c|}{ Area 4 (KRW 45 60 thousand) } \\
\hline & $\begin{array}{l}\text { Current individual land } \\
\text { price }\end{array}$ & Calculated land price & $\begin{array}{l}\text { Current individual land } \\
\text { price }\end{array}$ & Calculated land price \\
\hline Over $15 \%$ & $7 \%$ & $15 \%$ & $6 \%$ & $0 \%$ \\
\hline $5 \sim 15 \%$ & $11 \%$ & $8 \%$ & $10 \%$ & $1 \%$ \\
\hline$-5 \sim 5 \%$ & $45 \%$ & $69 \%$ & $50 \%$ & $54 \%$ \\
\hline$-5 \sim-15 \%$ & $24 \%$ & $8 \%$ & $22 \%$ & $44 \%$ \\
\hline Below $-15 \%$ & $12 \%$ & $0 \%$ & $13 \%$ & $0 \%$ \\
\hline Total & $100 \%$ & $100 \%$ & $100 \%$ & $100 \%$ \\
\hline \multirow{2}{*}{$\begin{array}{l}\text { Agricultural and } \\
\text { forest -agricultural } \\
\text { (paddies) }\end{array}$} & \multicolumn{2}{|c|}{ Area 7 (KRW 12 14 thousand) } & \multicolumn{2}{|c|}{ Area 8 (KRW 14 16 thousand) } \\
\hline & $\begin{array}{l}\text { Assessed individual } \\
\text { land price }\end{array}$ & Calculated land price & $\begin{array}{l}\text { Assessed individual } \\
\text { land price }\end{array}$ & Calculated land price \\
\hline Over $15 \%$ & $0 \%$ & $0 \%$ & $0 \%$ & $0 \%$ \\
\hline $5 \sim 15 \%$ & $3 \%$ & $0 \%$ & $6 \%$ & $0 \%$ \\
\hline$-5 \sim 5 \%$ & $85 \%$ & $100 \%$ & $91 \%$ & $100 \%$ \\
\hline$-5 \sim-15 \%$ & $12 \%$ & $0 \%$ & $3 \%$ & $0 \%$ \\
\hline Below $-15 \%$ & $0 \%$ & $0 \%$ & $0 \%$ & $0 \%$ \\
\hline Total & $100 \%$ & $100 \%$ & $100 \%$ & $100 \%$ \\
\hline
\end{tabular}


of calculated land prices by HLPAs, it was found that calculated land prices for Residential Zone Type 1-residential HLPAs showed a heightened balance between them and standard lot prices, compared with current individual land prices. In the case of Agricultural and Forest Zone - paddy HLPAs as well, it was found that the price balance between standard lots and individual lots improved greatly: $100 \%$ of HLPA 7 and HLPA 8 , which had a large number of lots within them, fell within the difference range of about \pm 5 from standard lot prices.

3) Balance between individual lands

The price balance between individual lots is analyzed using the coefficient of variation (CV). The coefficient of variation is defined as the ratio of the standard deviation to the mean (standard deviation/mean), and shows the degree of diversity in a region's land price distribution. The smaller the coefficient of variation, the evener the land price distribution; and the greater the coefficient of variation, the more diverse the land price distribution. Thus, from the size of $\mathrm{CV}$, it is possible to identify the degree of imbalance in land price distribution among lots in a relevant area.

When deriving and comparing the $\mathrm{CV}$ of calculated prices by HLPAs for the residential within the General Residential Zone
Type 2 and the CV of current individual land prices in Gangnam-gu, it was found that the HPLAs improved conspicuously the land price balance among lots, for the $\mathrm{CV}$ of calculated prices by HLPAs was considerably small compared with that of current assessed land prices, as shown in Table 11.

In Jangseong-gun also, as a result of comparing CVs of calculated prices for the HLPAs of the General Residential Zone Type 1 - residential and of the Agricultural and Forest Zone - paddies and CV of current assessed land prices, the analysis showed that in the residential HLPAs, the land price balance among individual lots improved 3.3 times in HLPA No. 3 and 6.6 times in HLPA No. 4, respectively, as shown in Table 12. In the HLPAs of the agricultural area - paddies also, the land price balance improved 3.0 times in HLPA No. 7 and 6.9 times in HLPA No. 8 , respectively, and thus, the land price balance in the calculated land prices by HLPAs was heightened conspicuously, compared with the current assessed land prices.

\section{Market value reflection degree}

What is pointed out as one of the typical problems of the officially assessed land price is the gap between it and market value due to its low degree of market value reflection. And it is not easy to raise the market value 
reflection degree of individual lots consistently, for some areas have market transaction prices of similar characteristics, others have only transaction data of different land characteristics. However, if HLPAs are classified, it is possible to use other area's market price data and analyze the difference from market price on a consistent basis; and thus the market price reflection degree can be heightened systematically among regions.

According to Kim Bong-joon et al. (2015), which analyzed five local cities including Nowon-gu in Seoul, it was found that the closeness to market value increased greatly among calculated prices by HLPAs. To enhance the adequacy of basic data used for HLPAs classification, Kim Bong-joon et al. classified HLPAs, using assessed individual land price data adjusted by market price. As a result of their analysis, it was found that most of calculated land prices within the relevant HLPAs were $95-110 \%$ of market prices and showed high closeness to market price, whereas officially assessed individual land prices showed $40-60 \%$ of market price. Calculated land prices higher than market prices in some regions are presumed to have resulted from two reasons: that ratios of assessed price to market price, which were higher than they actually were, were applied to lots and that low transaction prices were reported in order to reduce transfer and purchase taxes.

It is found that the fluctuation of the ratio of assessed price to market price by area also decreases sharply as shown in Fig. 5.

Table 11 Comparison of CVs at the General Residential Zone Type 2 in Gangnam-gu

\begin{tabular}{|c|c|c|c|c|c|c|}
\hline \multirow[b]{2}{*}{$\begin{array}{c}\text { General } \\
\text { Residential Zone } \\
\text { Type } 2 \text { - } \\
\text { residential }\end{array}$} & \multicolumn{2}{|c|}{ Area 15 (KRW 2.1 2.25 mil) } & \multicolumn{2}{|c|}{ Area 16 (KRW 2.25 2.4 mil) } & \multicolumn{2}{|c|}{ Area 17 (KRW 2.4 2.55 mil.) } \\
\hline & $\begin{array}{c}\text { Officially } \\
\text { Assessed } \\
\text { individual land } \\
\text { price }\end{array}$ & $\begin{array}{c}\text { Calculated land } \\
\text { price }\end{array}$ & $\begin{array}{c}\text { Officially } \\
\text { Assessed } \\
\text { individual land } \\
\text { price }\end{array}$ & $\begin{array}{c}\text { Calculated land } \\
\text { price }\end{array}$ & $\begin{array}{c}\text { Officially } \\
\text { Assessed } \\
\text { individual land } \\
\text { price }\end{array}$ & $\begin{array}{c}\text { Calculated land } \\
\text { price }\end{array}$ \\
\hline & 3.75 & 0.86 & 3.75 & 0.86 & 3.86 & 0.31 \\
\hline
\end{tabular}

Table 12 Comparison of CVs in Jangseong-gun

\begin{tabular}{c|c|c|c|c}
\hline \multirow{2}{*}{$\begin{array}{c}\text { General Residential } \\
\begin{array}{c}\text { Zone Type 1 } \\
\text { residential }\end{array}\end{array}$} & \multicolumn{2}{|c|}{ Area 3 (KRW 30 45 thousand) } & \multicolumn{2}{c}{ Area 4 (KRW 45 60 thousand) } \\
\cline { 2 - 5 } & $\begin{array}{c}\text { Officially Assessed } \\
\text { individual land price }\end{array}$ & Calculated land price & $\begin{array}{c}\text { Officially Assessed } \\
\text { individual land price }\end{array}$ & Calculated land price \\
\cline { 2 - 5 } & 28.23 & 8.59 & 25.71 & 3.92 \\
\hline \multirow{2}{*}{$\begin{array}{c}\text { Agricultural and } \\
\text { Forest Zone } \\
- \text { paddies }\end{array}$} & \multicolumn{2}{|c|}{ Area 7 (KRW 12 14 thousand) } & \multicolumn{2}{|c|}{ Area 8 (KRW 14 16 thousand) } \\
\cline { 2 - 5 } & $\begin{array}{c}\text { Officially Assessed } \\
\text { individual land price }\end{array}$ & Calculated land price & $\begin{array}{c}\text { Officially Assessed } \\
\text { individual land price }\end{array}$ & Calculated land price \\
\cline { 2 - 5 } & 16.44 & 5.42 & 13.53 & 1.98 \\
\hline
\end{tabular}




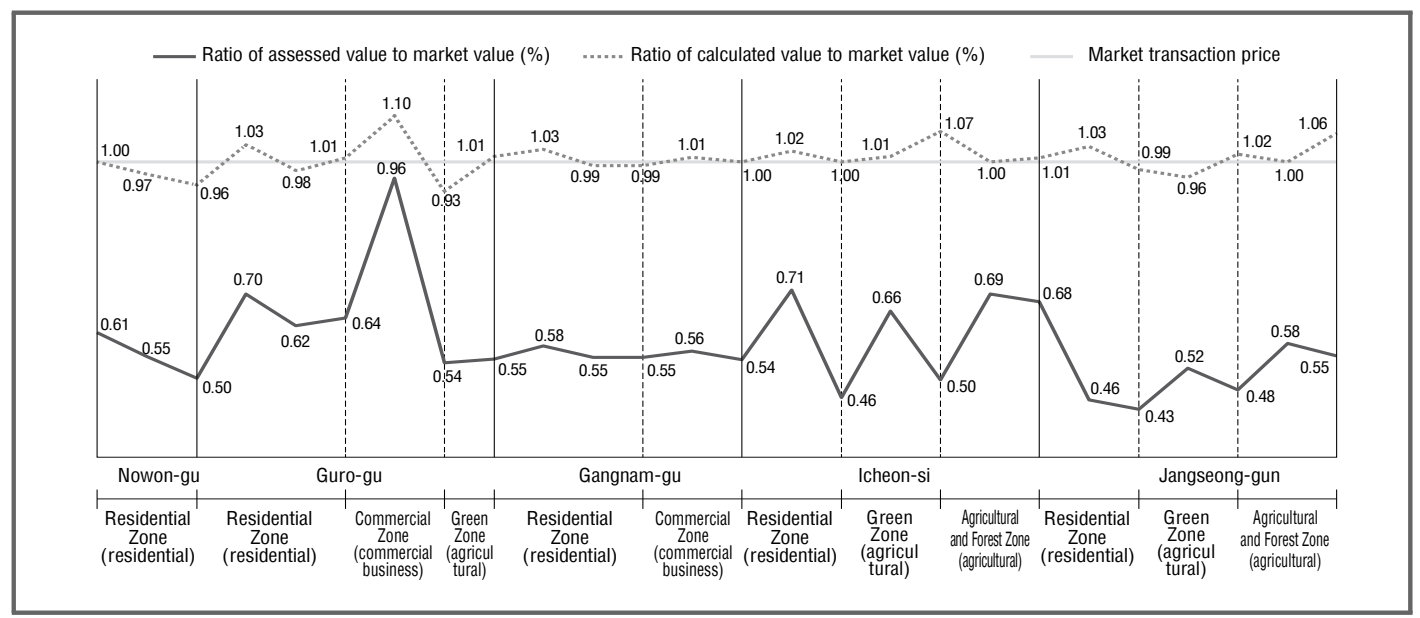

Source: Kim Bong-joon et al., 2015, op. cit., p.102.

Fig. 5. Comparison of market value reflection degrees

Therefore, it is judged that the future utilization of HLPAs will systematically reduce the gap between the market prices and the officially assessed land prices and thus will be able to increase the reliability of officially assessed land prices.

\section{Synthesis and implications of analysis}

It has been found that the method of HLPAs classification analyzed so far improves in terms of three criteria, that is, the standard lot management, the land price balance, and the market price reflection degree, compared with the current assessment method of land price. From this process for verifying the adequacy of the HLPAs, the following implications may be derived.

First, classification of HLPAs can enhance the rationality of standard lot allocation and the efficiency of standard lot management. Since one standard lot is selected in each HLPA, the duplicate allocation of standard lots of similar characteristics can be reduced, and thus the number of standard lots decreases, and difficulty in the selection of comparative standard lot can be alleviated fundamentally. Lands across the country may be classified into approximately 233,000 HLPAs. This means that about 233,000 standard lots to the maximum are enough to provide reference price to all the HLPAs across the country. Even when one HLPA has many lots, or lots are spatially separated, there is no difficulty in the selection of comparative standard lot and the calculation of individual land price, for lists of lot numbers are classified by computer according to 


\section{HLPAs.}

Second, the HLPAs can be used as a means of enhancing the adequacy of scales in the land price index table. Since HLPAs are classified on the basis of key land price determinants and similar land price levels, land price index tables prepared according to HLPAs can analyze relatively appropriate price scales based on differences in micro-characteristics from neighboring lots. As a result of preparing micro-index tables by HLPAs in this paper, it was found that scale differences by land characteristics decrease and that the system of scale changes is stable. This implies that the problem of the land price imbalance among neighboring lots can be reduced greatly. In addition, in case that lands are located on boundaries of administrative districts, the HLPAs will be able to resolve the problem of land price imbalances between regions resulting from great price differences caused by calculating land prices on the basis of comparative standard lots in different administrative districts though the lands belong to an HLPA.

Third, in terms of land price balance, the HLPA enhances the price balance between the standard lot and individual lands and between individual lands. As a result of verifying the price balance between the standard lot and individual lands by HLPA, it was found that the calculated land price shows a price level closer to the standard lot price than the current officially assessed individual land price and that the $\mathrm{CV}$ of individual land prices within an HLPA is considerably lower than that of the current officially assessed individual land prices, showing the improved balance between individual lots. These findings may be viewed as the results of applying HLPAs classified by reflecting the range of subtle land price changes and the determinants of land price changes.

Fourth, in case of valuating and assessing the standard lot, the land price is calculated on the basis of market transaction cases, using the market comparison approach; and the HLPAs can be used as a means of selecting a suitable transaction case easily from other area even though there is no transaction case in the neighborhood. That is, a transaction case may be found in other administrative district having similar land price determinants and land price level, even though it is not located in the same administrative district. Officially assessed individual land prices as well as officially assessed standard lot price can be calculated directly from the market price, using the HLPAs. And if the land prices are calculated, using several market prices, not one market price, within the HLPA or neighboring HLPAs, and the mean price is calculated after excluding extreme prices, a more stable price can be calculated 
than when data on one or two transaction cases are used.

Fifth, since HLPAs are analyzed based on administrative districts, key land price determinants and land price levels, land characteristics or land price levels that don't suit the land use or regional characteristics can be easily identified; and thus, the HLPAs can also be used as a means of analyzing an error in a land characteristic survey.

\section{Conclusion}

The significance and necessity of the HLPAs in appraisal and the OASLP have been continuously raised meanwhile; however, methods for their implementation have not been found due to difficulty in determining the definite spatial boundaries of the HLPAs. This paper reestablished the concept of HLPAs and proposed their classification method.

It was found that the method of HLPAs classification proposed by this paper can classify HLPAs in a prompt and consistent manner by reducing arbitrariness. In addition, HLPAs can enhances the efficiency of standard lot management and improve the price balances between lots.

As a method for HLPAs classification, this paper classified HLPAs based on officially assessed individual land prices and examined their validity by applying the ratio of assessed prices to market prices. In the future, work should be conducted that enhances the adequacy of the HLPAs classification by increasing the accuracy of basic data through complementing the problems of officially assessed individual land prices such as survey errors in land characteristics as well as analyzing market prices systematically.

At an early stage, the HLPAs classification is carried out within the local administrative boundary in order to reduce the risk caused by the limitations of basic data; once the HLPAs classification is stabilized to some extent, a plan for developing the classification into a means to raising the land price balance between regions by gradually expanding it to metropolitan areas and provinces should also be considered.

\section{References}

Chae, M. O., 1993, Review on Fair Market Value and Assessed Price, The Korea Spatial Planning Review, 19. (in Korean)

Chae, M. O., 1994, Long-term Direction of the Development of the Assessed Land Price Survey and Evaluation System, Korea Research Institute for Human Settlements. (in Korean)

Chae, M. O., 2006, Review on Methods for the Improvement of Public Notification System of Land Price upon Implementation of the 
Real Estate Transaction Price Report System, The Korea Spatial Planning Review, 49: 134. (in Korean)

Chae, M. O. and Kwon, T. H., 1997, A Study on the Enhancement of Proportionality and Accuracy of Public Land Price, Korea Research Institute for Human Settlements. (in Korean)

Chae, M. O. and Moon, K. H., 1999, Long-Term Policy Directives on the Posted Land Price System, Korea Research Institute for Human Settlements. (in Korean)

Chae, M. O., Jung H. N. and Song, H. S., 2003, Direction of land policy towards the era of $\$ 20,000$ income, Seminar on the direction of SOC and land policies towards the era of $\$$ 20,000 income, Korea Research Institute for Human Settlements. (in Korean)

Kim, B. J. and Choi, J. H., 2015, A study on method of classification of similar price zone, Seminar on the methods for the advancement of homogeneous price area classification (II), Korea Appraisal Board. (in Korean)

Kim, B. J., Choi, J. H. and Lee, G. Y., 2015, Seminar on the methods for homogeneous price area classification: A Study on method of classification of similar price zone, Korea Appraisal Board. (in Korean)

Kim, Y. P., 1985, Measurement of development merit, Land Policy, Administration \& Culture Institute, 662. (in Korean)

Lee, T. I., and Chae, M. O., 1986, Statistical Evaluation Methods based on Land Price Model, The Korea Spatial Planning Review, 5: 23. (in Korean)

Ministry of Land, Infrastructure, and Transport, 2015, Guidelines on the Survey and Calculation of Officially Assessed Land Price, p. 134. (in Korean)

Yang, S. C., Lee, S. W. and Jang, G. C., 2006, A study on methods and standards for the
HLPAs for the calculation of officially assessed individual land prices, Ministry of Construction and Transportation. (in Korean)

Yi, S. K., Park, S. H. and Hong, S. E., 2001, A Similar Price Zone Determination of Public Land Price Using a Hybrid Clustering Technique, Journal of The Korean Geographic Society, 41(1). (in Korean)

Received: 16 Oct. 2015

Reviewed (Revised): 1st, 26 Oct. 2015

2nd, 22 Nov. 2015

Accepted: 27 Nov. 2015

Published online: 31 Dec. 2015 